\title{
Understanding Scientific Literacy and Pedagogy Competence: A Critical Insight into Religious Integration Thinking Skills
}

\author{
Ahmad Zainuri \\ State Islamic University of Raden Fatah of Palembang, \\ Jl. Prof. K. H. Zainal Abidin Fikri No.Kel, Pahlawan, Kec. Kemuning, \\ Kota Palembang, Sumatera Selatan 30126, Indonesia \\ Sukarno \\ State Islamic University of Sulthan Thaha Saifuddin of Jambi, \\ Jl. Arif Rahman Hakim No.111, Simpang IV Sipin, Kec. Telanaipura, \\ Kota Jambi, Jambi 36361, Indonesia \\ Miftachul Huda \\ National Child Development Research Center and Faculty of Human Sciences, \\ Universiti Pendidikan Sultan Idris, Proton City, \\ 35900 Tanjung Malim, Perak, Malaysia \\ Corresponding Author
}

DOI: https://doi.org/10.36941/jesr-2022-0022

\section{Abstract}

This study aims to examine the scientific literacy and pedagogical competence on the ability to comprehend the religious integration amongst Islamic education pre-service teachers. This research used a quantitative approach involving 156 participants from several universities. Data were obtained through conducting survey. Data analysis was performed with bivariate correlation. Based on the data analysis carried out, the finding showed that the significant correlation between scientific literacy skills and pedagogy competence to the ability of religious integration thinking skills within Islamic religious content and values. This is based on the value of sig. (2-tailed) between X1 (Science Literacy) to the integration ability obtained that the value of 0 ,ooo, which means <0.05. This data proves that there is a significant correlation between the ability of scientific literacy skills and pedagogy skills to the ability of science integration comprehension amongst the Islamic education pre-service teachers.

Keywords: scientific data literacy, pedagogy skills, religious educator, integration of science values, Islamic religion learning

\section{Introduction}

Literacy science is defined as a skill related to the ability to use scientific knowledge for life. This is in line with the explanation of Zuriyani, (2011), Arohman, Saefudin, \& Priyandoko, (2016) that scientific 
literacy is the ability to utilize scientific knowledge or scientific knowledge. Science literacy is the ability to understand, communicate science and apply that ability to make scientific decisions (Bahrudin et al., 2021; Yulyanti, 2017). According to Winata, Cacik, \& Widiyanti (2018) scientific literacy is knowledge and understanding of scientific concepts and processes for making personal decisions. Science literacy capabilities include the ability to identify problems, collect data and information and also proceed the data obtained and draw conclusions in accordance with the data and information (Huda and Hashim, 2021; Kusufa, 2019).

The ability of scientific literacy is one of the most important abilities needed by each individual to improve the quality of human life itself. With good scientific literacy, the development of science and technology will be more environmentally friendly so that natural damage can be avoided. However, the lack of scientific literacy ability will not only hamper the development of science and technology but will also have an impact on the lack of sensitivity to the surrounding natural damage as a negative impact of the development of science and technology and the lack of knowledge of the potential for local excellence (Nofiana \& Julianto; 2018). Therefore, the ability of scientific literacy must be possessed and controlled not only for people who work in the fields of science and technology, but also who work in social fields. Even Rahayu, (2017) mentioned that literacy is very important to be taught to students in this century. (Yulyanti, 2017) also said that scientific literacy is very urgent and must be owned by every student (individual) in this global era. Science literacy is really needed by each individual (students) as a basic material in terms of solving problems in life and increasing the ability to adapt to the environment (Ayuningtyas, 2016; Huda et al., 2021a). People who are literate in science will have the ability to recognize and understand various kinds of information (data), analyze obtained, organize data, make decisions based on information (data) obtained and can apply these decisions appropriately (Rizkita, Suwono, \& Susilo, 2016).

Based on the description above it appears that scientific literacy is very important for teachers as facilitators of the development of scientific literacy of the students. With good scientific literacy skills teachers will be able to relatively easily gather the variety of information related to the ability of students, student background, interests, talents, and learning resources that are most appropriate for the situation of students. Also with scientific literacy skills, teachers will be able to better plan, implement and assess learners' abilities, since overall these points are closely related to the ability of scientific literacy. If it is associated with the teaching profession, then the ability above is part of the ability or competence of pedagogy.

Pedagogical competence or ability is one of the abilities that is very important for teachers and other educators. With good pedagogical skills the teacher will be able to plan learning more accurately, deliver teaching materials better, build a more pleasant learning atmosphere, and make instruments and teaching materials according to students' needs. This is in line with the opinion (Fathorrahman, 2017) that pedagogical competencies include; the ability to understand the character of students, the ability to plan and implement learning activities, the ability to assess student learning outcomes, and the ability to explore the potential of students. Pedagogy is a science that is both practical and theoretical. Science also involves many other fields of study, such as psychology, social sciences, learning methods, education philosophy and sociology (Huda et al., 2021b; Kumala, Susilo, \& Susanto, 2018). Therefore, pedagogical skills must be possessed by teachers or other professional educators. This is due to the fact that pedagogy is closely related to success in teaching and learning. In Indonesia, pedagogical competence is one of the main requirements to become a professional teacher (Sutarmanto, 2015). The teacher's pedagogical ability determines his success in teaching. With this ability teachers can improve student achievement (Wulandari, 2012; Dewi, Suharsono, \& Haris, 2014; Purnamawanti, Suliswiyadi, \& Nugroho, 2018) increase the effectiveness of the learning process (Andini \& Supardi, 2018; Deassy May Andini, 2018) and student motivation (Pratiwi, 2018). Other research results also found that pedagogic abilities also affect the ability of teachers to implement learning strategies, models and media (Karom, 2014) as well as in implementing curriculum (Falachi, Kartana, \& Utami, 2017).

In addition, the teacher's pedagogical ability also influences his own development. In one study 
it was also mentioned that pedagogical competencies were able to contribute to teacher performance up to 6.9\% (Salmawati, Rahayu, \& Lestari, 2017; Hadi, 2018) and work motivation (Supriyono, 2017). SapIslamic educationle (2017) also found that pedagogical abilities directly influence that can improve teacher assessment performance. Other research results also state that pedagogical ability is strongly correlated with basic teaching abilities and skills (Dirgantoro, 2019). It is therefore natural that researcher, for example, Sakti, Hairunisya, and Sujai (2019) say that the teacher's ability to teach pedagogical competence greatly influences and determines the development of future education processes. In the context of Islamic education, it is believed that Islamic teachings are a perfect system and perfect the previous religions (Rasyid, 2016). As religion with perfect teachings, the teachings of Islam encompass the whole structure of human life, including in terms of education. It is believed that there is a close relationship between science and Islam as a perfect religion. Islam strongly encourages mankind to continually seek knowledge and place a high degree of knowledgeable people (Hasyim, 2013).

By reason of the strong link between Islam and science, various attempts were made to integrate Islamic values into science, and vice versa, namely integrating scientific values into Islam. One of the real efforts made in integrating the two things is through trains in formal educational institutions (Muttaqin, 2018). In addition, the development of scientific literacy based on Islamic values and local culture is also carried out (Asyhari, 2017), integration of Islamic values in science learning in schools (Muspiroh, 2013). In addition, efforts at integration are also pursued through the development of a particular teaching material, for example in the form of modules (Yuliawati, Rokhimawan, \& Suprihatiningrum, 2013; Hamzah, 2016), also modules in the form of Braille (Mukaromah, 2018), development of physics learning tools on Islamic values (Winarti, 2017). Further efforts are made through the use of certain learning approaches, for example lesson study (Zetty, Rashidah, Norshilawani, Syafiq, \& Zanaton, 2017), as well as through approaches to certain subjects, such as Natural Sciences (Rahmawati \& Bakhtiar, 2019).

Based on a review of the research results above, it appears that science and Islam have a strong relationship. In the context of Islam as a perfect religion, science is one of its teachings. However, there are several groups and schools that continue to try to separate Islam and science, and some even say that science and technology threaten Islam as a religion (Azhar, 2010). Related to this, Islamic education has an important role in the effort to integrate science and Islam. This, as stated by Firmansyah (2016) that the Quran and Hadith are sources of religious and scientific law. Thus, in fact there is no term dichotomy between religion and science (Imron, 2018). Therefore Saftri \& Sa'dudin (2019) emphasized that the integration (integration) between religion and science is a step forward in the development of existing scholarship.

Referring to the explanation above, namely between scientific literacy, pedagogical competence and integration are very important and warm variables to be discussed, and are included in new breakthroughs in scientific development (Saftri \& Sadudin, 2019). These three variables have a close relationship and are believed to have a strong influence on each other. Therefore, the focus in this study is to look at answering the question on how the effect of science literacy skill and pedagogical competence on integration ability of science values in Islamic education preservice teacher.

\section{Method}

This research is included in the survey research category. In this study involved 156 pre-service teachers of Islamic education from several Islamic Universities as respondents. Respondents involved in this study were Islamic education pre-service teachers who had taken part in lectures: (1) learning methods and strategies, (2) learning design, (3) educational psychology, and (4) curriculum analysis, and (5) assessment of learning outcomes learners. This is done with the consideration that the five courses are closely related to the ability of pedagogy. In general, students who have taken the course are in semesters 4-6. Research uses a quantitative approach. Data for variables, religious literacy skills and pedagogical competencies were carried out by conducting tests. Test instruments were arranged 
based on each indicator. The indicators of scientific literacy refers to the capability consisting of (a) recognizing and understanding various kinds of information or data, (b) analyzing and organizing data, (c) making decisions based on the information or data obtained and (d) ability to apply science knowledge appropriately (Rizkita et al., 2016). The indicators used to measure the pedagogy competencies include (a) the ability to understand the character of students, (b) the ability to plan, (c) carry out learning activities, (d) the ability to assess student learning outcomes (Fathorrahman, 2017).

Thus each variable, both scientific literacy and pedagogical competency, uses four indicators arranged in the form of multiple choice test questions. Each variable is measured by 40 multiple choice questions. Thus, the maximum score on these two variables is 40 points. The ability to integrate science values in Islamic education is conducted amongst Islamic education pre-service teachers. Both in the form of products (concepts, theory, law and technology), processes (observation, classification, measurement, searching and finding data, processing data, making conclusions, communicating, etc.) and scientific attitudes (honest, objective, thorough, careful, careful, open, etc.). The ability to integrate scientific values is measured using an assessment rubric. The assessment rubric is used for products that have been developed by Islamic education teacher candidates, in this case in the form of lesson plans and material content. The rubric used uses the Likert scale with the provisions of: a) score 4 (very good), b) score 3 (good), c) score 2 (not good), and d) score 1 (not good), and e) score o (no integration). The rubric used in this study is 10 questions, so the maximum score obtained is 40 points and the minimum score is o. To find out how much influence the scientific literacy, pedagogical abilities have on the ability to integrate science into Islamic education learning, an analysis of the data has been obtained.

\section{Results}

3.1 Science literacy ability, pedagogical competence and science value integration ability in learning amongst Islamic education teacher candidates

Based on the results of tests / measurements carried out by involving indicators of scientific literacy, pedagogical competence and the ability to integrate the value of science in the learning of prospective of Islamic education teacher students are as follows:

Table 1: Categories of the ability of Islamic education teacher candidates in three aspects

\begin{tabular}{|c|c|c|c|c|}
\hline Aspect & Score & Total & Percentage (\%) & Category \\
\hline \multirow{4}{*}{ Science Literacy } & $29-40$ & 24 & 15,38 & High \\
\hline & $14-28$ & 54 & 36,41 & Medium \\
\hline & $0-13$ & 78 & 50 & Low \\
\hline & Total & 156 & 100 & \\
\hline \multirow{4}{*}{ Pedagogical Competence } & $29-40$ & 56 & 35,89 & High \\
\hline & $14-28$ & 56 & 35,89 & Medium \\
\hline & $0-13$ & 44 & 28,20 & Low \\
\hline & Total & 156 & 100 & \\
\hline \multirow[t]{4}{*}{ Integration Expert } & $29-40$ & 32 & 20,51 & High \\
\hline & $14-28$ & 56 & 35,89 & Medium \\
\hline & $0-13$ & 68 & 43,58 & Low \\
\hline & Total & 156 & 100 & \\
\hline
\end{tabular}

Based on Table 1, it can be seen that in general, the pedagogical skill of Islamic education teacher candidates is better than the scientific literacy ability and integration ability. This can be understood because, in general, Islamic education teacher candidates do not get courses related to science. 
Whereas the ability of scientific literacy is very closely related to natural knowledge that they did not learn except when they were in elementary and secondary education. As for the ability of integration, it is still dominated by the ability with low categories, which is as much as $43.58 \%$, because this ability also involves the ability of science. Thus, if examined, the ability of scientific literacy and the ability of integration have a close percentage level, so it is allegedly strong; the two variables have a correlation.

\subsection{Correlation between Ability of Scientific Literacy and Pedagogical Ability on Integration of Science Value in Islamic Education}

Based on the data that has been obtained then performed an analysis with the help of SPSS software, the analysis in question is the bivariate product moment correlation analysis. The results of this analysis can be seen in the following Table 2 :

Table 2: Correlations

\begin{tabular}{|c|c|c|c|c|}
\hline & & Science Literacy & Pedagogy Ability & Integration Ability \\
\hline \multirow[t]{3}{*}{ Science Literacy } & Pearson Correlation & 1 & .066 & $.371^{* *}$ \\
\hline & Sig. (2-tailed) & & .411 & .000 \\
\hline & $\mathrm{N}$ & 156 & 156 & 156 \\
\hline \multirow[t]{3}{*}{ Pedagogy Ability } & Pearson Correlation & .066 & 1 & $.342^{* *}$ \\
\hline & Sig. (2-tailed) & .411 & & .000 \\
\hline & $\mathrm{N}$ & 156 & 156 & 156 \\
\hline \multirow[t]{3}{*}{ Integration Ability } & Pearson Correlation & $.371^{* *}$ & $.342^{* *}$ & 1 \\
\hline & Sig. (2-tailed) & .000 & .000 & \\
\hline & $\mathrm{N}$ & 156 & 156 & 156 \\
\hline
\end{tabular}

**. Correlation is significant at the o.o1 level (2-tailed).

Based on the value of sig. (2-tailed) between $\mathrm{X}_{1}$ (science literacy) to integration ability, it was found that the value is 0,000 which means $<0.05$. This data proves that there is a significant correlation between the ability of LS to the ability of integration of Islamic education teacher candidates. Besides that the value of sig. (2-tailed) $\mathrm{X}_{2}$ (pedagogical ability) towards integration capability is $0,000<0.05$. Therefore, this also shows that the ability of pedagogy also significantly influences the ability of integration of Islamic education teacher candidates. Correlation data also shows that the calculated $\mathrm{R}$ value (Pearson correlation), it is known that the Rhitung is $0.371>$ Rtable 0.1562 , which means that there is a significant correlation between SL and IA. The PA data has Rhitung $0.342>$ Rtabel 0.1562 which means that there is a significant correlation between PA and IA. In addition, when viewed based on SPSS analysis with an asterisk $\left(^{*}\right)$, it appears that the two variables have two star bunches $\left({ }^{* *}\right)$, it means that there is a significant correlation.

\section{Analysis and Discussion}

As stated above that the ability of scientific literacy and pedagogical competence affect the ability of Islamic education teacher candidates to integrate science values into the learning of Islamic religious education. This finding indicates that there is a close relationship between the three variables. With the close relationship between the variables above to prospective teachers of Islamic religion need to get training or technical guidance to improve the ability of scientific literacy as well as pedagogical competence (Maseleno et al., 2021). With adequate scientific literacy, teachers will follow the development of science and technology better. One of the demands of teachers in this modern age is the ability to adapt to new technologies (Anshari et al., 2017; Lase, 2019). As it is known that the teacher is the front front in developing students' abilities, including in increasing scientific literacy 
(Susanti \& Syam, 2017). So the results of this study provide encouragement so that prospective teachers (including prospective teachers of Islamic education) need to get assistance in increasing scientific literacy. One of the efforts that can be done in order to improve the ability of scientific literacy of prospective teachers is through learning based on Natural of Science (NOS) (Rahayu, 2016).

Referring to the opinion of Narut \& Supradi, (2019) that literacy is scientific knowledge and skills in terms of: 1) identifying and asking questions, 2) obtaining new data or information as knowledge, 3) able to describe natural events scientifically, 4) making conclusions based on information or data obtained, 5) know and understand the nature of science, 6) understand the impact of the development of science and technology on the environment, 7) care about scientific issues. Thus, other efforts that can be made to improve the scientific literacy skills of prospective teacher students are to practice the abilities above through a variety of relevant courses. Some courses can be used as a means to improve teacher's scientific literacy, for example; teaching and learning strategies, teaching practices (Rahayu, 2016), learning design, assessment of learning outcomes and so

on.

The results of this study also showed that the ability of pedagogy can also directly affect the ability of Islamic education teacher candidates to integrate science values into Islamic education learning. This can be understood considering pedagogical competence involves the ability to plan, implement and assess student learning outcomes (Mulyadi, Huda and Gusmian, 2022). Therefore, the integration of science values can be done by (prospective) teachers since they formulate learning plans, implementation of learning and assessment of learning outcomes. With good pedagogical skills and scientific literacy, the elements of science will easily be found in the study of Islamic religion.

As it is known that science is part of the teachings of Islam, the integration of science into the learning of Islam is a necessity. One way to do this integration is through an interdisciplinary approach (Asyhari, 2017). The interdisciplinary approach is one of the efforts in solving problems from various appropriate scientific perspectives (Rohmatika, 2019), in this case is the science and religion of Islam. Through this approach, the relationship or connections between the concepts involved in the integration will become clearer. Other efforts that can be made to integrate the values of science and Islam through the lesson study approach (Zetty Nurzuliana et al., 2017). Through lesson study activities involving science teachers and Islamic religion teachers will facilitate teachers in integrating science values into Islamic religious learning, and vice versa. In relation to this research, lesson study can be changed into collaboration between Islamic religion teacher candidates and science teacher candidates (physics, biology, chemistry and mathematics). Together, they can create an integrated learning plan.

Integrating the values of science and Islam can also be done with the Al-Qur'an-ScienceCharacter approach or known by the term ALSAK (Winarto, Zahro, \& Ardiyansyah, 2018). Through this approach prospective teacher students are trained to develop learning tools that involve the Quran, science and character together. The intended learning tool can be: syllabus, lesson plans, and student worksheets. Through this approach, prospective teacher students will get a good opportunity to produce preparations for teaching integration of science and the Quran. This approach will also be able to improve the literacy of science and pedagogical competence of Islamic education teacher candidates.

\section{Conclusion and Recommendation}

Based on the data that has been obtained and data amalgamation that has been done and the discussion as described above, it can be concluded that the significant correlation between the two variables namely $\mathrm{X}_{\mathbf{1}}$ (scientific literacy ability) and $\mathrm{X}_{\mathbf{2}}$ (pedagogical ability) to $\mathrm{Y}$ variable ( the ability to integrate Islamic religious content and scientific values). This is based on the value of sig. (2-tailed) between $\mathrm{X}_{1}$ (Science Literacy) to the integration ability obtained that the value of 0,000 , which means $<0.05$. This data proves that there is a significant correlation between the ability of LS to the ability of integration of 
prospective teachers of Islamic education. Besides that the value of sig. (2-tailed) X2 (pedagogical ability) towards integration capability is $0,000<0.05$. Therefore, this also shows that the ability of pedagogy also significantly influences the ability of integration of Islamic education teacher candidates. Correlation data also shows that the value of Rhitung (Pearson correlation), it is known that the Rhitung is $0.371>$ Rtabel 0.1562 , which means that there is a significant correlation between scientific literacy and integration ability. The pedagogical ability data has a Rhitung $0.342>$ Rtable 0.1562 which means that there is a significant correlation between the ability of pedagogy to the ability of integration. In addition, when viewed based on SPSS analysis with an asterisk (*), it appears that the two variables have two star bunches $\left({ }^{* *}\right)$, it means that there is a significant correlation. Based on the results of the study as described above, it is clearly seen that the three variables, namely: the ability of scientific literacy, pedagogical competence and the ability to integrate scientific values in Islamic religious education learning have a significant correlation. Therefore, at the end of this study, several suggestions could be pointed out as follow. There needs to be science-based or science-oriented courses for prospective teachers of Islamic religious education. In addition to providing opportunities for enhancing the ability of scientific literacy, it also can indirectly improve the ability to integrate the values of science into the learning of Islamic religious education. There needs to be a teaching material model that integrates science values with Islamic religious education content. With this model teaching material, it is expected to be able to inspire prospective Islamic teacher education students to develop learning plans, develop teaching materials and make better assessment tools of learning integration outcomes.

\section{References}

Andini, D. M., \& Supardi, E. (2018). Kompetensi Pedagogik Guru Terhadap Efektivitas Pembelajaran Dengan Variabel Kontrol Latar Belakang Pendidikan Guru. Jurnal Pendidikan Manajemen Perkantoran. https://doi.org/10.17509/jpm.v3i1.9450

Anshari, M., Almunawar, M. N., Shahrill, M., Wicaksono, D. K., \& Huda, M. (2017). Smartphones usage in the classrooms: Learning aid or interference?. Education and Information Technologies, 22(6), 3063-3079.

Arohman, M., Saefudin, \& Priyandoko, D. (2016). Kemampuan Literasi Sains Siswa pada Pembelajaran Ekosistem. Proceeding Biology Education Conference.

Artha, R., Junaedi, J., Maseleno, A., Huda, M., \& Ibrahim, M. H. (2021). Improving clean and healthy Islamic educational institution. Linguistics and Culture Review, ${ }_{5}\left(\mathrm{~S}_{1}\right)$.

Asyhari, A. (2017). Literasi Sains Berbasis Nilai-Nilai Islam dan Budaya Indonesia. Jurnal Ilmiah Pendidikan Fisika Al-Biruni. https://doi.org/10.24042/jpifalbiruni.v6i1.1584

Ayuningtyas, R. S. (2016). Profil Kompetensi Literasi Sains Siswa Berdasarkan The Programme for International Student Assesment (PISA) pada Konten Biologi. Published Undergraduate Thesis of Universitas Lampung.

Azhar, B. A. (2010). Faktor pembangunan dan kemunduran pengajian sains Islam silam. Jurnal Hadhari.

Bahrudin, B., Ritonga, M., Maseleno, A., Huda, M., \& Ibrahim, M. H. (2021). Social learning for understanding planning practices at the individual level. Linguistics and Culture Review, $5(1)$.

Deassy May Andini, E. S. (2018). Kompetensi Pedagogik Guru Terhadap Efektivitas Latar Belakang Pendidikan Guru. Pendidikan Manajemen Perkantoran.

Dewi, L. R., Suharsono, N., \& Haris, I. akhmad. (2014). Pengaruh Kompetensi Pedagogik Dan Kompetensi Profesional Terhadap Hasil Belajar Siswa Dalam Mata Pelajaran Ekonomi Kelas X SMAN 4 Singaraja. Tahun.

Dirgantoro, K. P. S. (2019). The effect of academic and pedagogic competences on basic teaching skills of mathematics teacher candidates in micro teaching. Math Didactic: Jurnal Pendidikan Matematika. https://doi.org/10.33654/math.v5i2.604

Falachi, H., Kartana, T. J., \& Utami, W. B. (2017). Pengaruh Penerapan Kompetensi Pedagogik Guru Dalam Pembelajaran Matematika Berbasis Kurikulum 2013 Terhadap Prestasi Belajar Matematika Peserta Didik Tahun Pelajaran 2016/2017. AKSIOMA. https://doi.org/10.26877/aks.v8i1.1508

Fathorrahman. (2017). Kompetensi pedagogik, profesional, kepribadian, dan kompetensi sosial dosen. Akademika.

Firmansyah, R. A. (2016). Kemampuan Mahasiswa Pendidikan Kimia dalam Menganalisis Ayat-ayat Kauniyah yang berasal dari Al-Quran dan As-Sunnah sebagai Petunjuk Pengembangan Kimia Berbasis Wahyu. Phenomenon : Jurnal Pendidikan MIPA. https://doi.org/10.21580/phen.2015.5.1.94

Hadi, S. (2018). Pengaruh Kompetensi Pedagogik Dan Kompetensi Profesional Terhadap Kinerja Guru Bimbingan Dan Konseling Di SDLB Kota Bandung. Jurnal Ilmu Politik Dan Komunikasi. https://doi.org/10.34010/jipsi.v8i1.877 
Hamzah, F. (2016). Studi Pengembangan Modul Pembelajaran Ipa Berbasis Integrasi Islam - Sains Pada Pokok Bahasan Sistem Reproduksi Kelas IX Madrasah Tsanawiyah. Adabiyah: Jurnal Pendidikan Islam. https://doi.org/10.21070/ja.vii1.163

Hasyim, B. (2013). Islam Dan Ilmu Pengetahuan (Pengaruh Temuan Sains terhadap Perubahan Islam). Jurnal Dakwah Tabligh.

Huda, M., Gusmian, I., \& Mulyo, M. T. (2021a). Towards Eco-Friendly Responsibilities: Indonesia Field School Model Cross Review. Journal of Comparative Asian Development (JCAD), 18(2), 1-12.

Huda, M., Mustafa, M. C., \& Mohamed, A. K. (2021b). Understanding of Multicultural Sustainability through Mutual Acceptance: Voices from Intercultural Teachers' Previous Early Education. Sustainability, 13(10), 5377 .

Huda, M. and Hashim, A. (2021). Towards Professional and Ethical Balance: Insights into Application Strategy on Media Literacy Education. Kybernetes. DOI 10.1108/K-07-2017-0252

Imron, A. (2018). Implementasi Pengembangan Materi Islamic education Mi Perspektif Integrasi Interkoneksi. MAGISTRA: Media Pengembangan Ilmu Pendidikan Dasar Dan Keislaman. https://doi.org/10.31942/mgs.v8i1.2003

Karom, D. (2014). PEngaruh Kompetensi Pedagogik Guru Dalam Menerapkan Pembelajaran Kooperatif Berbantuan Media Presentasi Terhadap Hasil Belajar Peserta Didik Pada Mata Pelajaran Matematika. EDUTECH. https://doi.org/10.17509/edutech.v13i2.3113

Kumala, V. M., Susilo, J., \& Susanto, R. (2018). Hubungan Pengetahuan Pedagogik Dengan Kompetensi Pedagogik Serta Perbedaannya Di Sekolah Negeri Dan Sekolah Swasta. Hubungan Pengetahuan Pedagogik Dengan Kompetensi Pedagogik Pentingnya.

Kusufa, R. A. B. (2019). Pengaruh Kompetensi Pedagogik Dan Kesiapan Guru Terhadap Implementasi Kurikulum 2013. JPIG (Jurnal Pendidikan Dan Ilmu Geografi). https://doi.org/10.21067/jpig.v2i2.3506

Lase, D. (2019). Pendidikan di Era Revolusi Industri 4.o. SUNDERMANN Jurnal Ilmiah Teologi Pendidikan Sains Humaniora Dan Kebudayaan. https://doi.org/10.36588/sundermann.vii1.18

Maseleno, A., Huda, M., Marzuki, M., Leh, F. C., Hashim, A., \& Ibrahim, M. H. (2021). Translating Islamic identity into numbers. Linguistics and Culture Review, 5(S1), 139-159.

Mukaromah, S. M. (2018). Pengembangan Modul IPA Braille Berbasis Integrasi Islam dan Sains. INKLUSI. https://doi.org/10.14421/ijds.050203

Mulyadi, D., Huda, M., \& Gusmian, I. (2022). Smart Learning Environment (SLE) in the Fourth Industrial Revolution (IR 4.o): Practical Insights Into Online Learning Resources. International Journal of Asian Business and Information Management (IJABIM), 13(2), 1-23.

Muspiroh, N. (2013). Integrasi Nilai-nilai Islam dalam Pembelajaran IPA di Sekolah. Jurnal Pendidikan Islam. https://doi.org/https://doi.org/10.15575/jpi.v28i3.56o

Muttaqin, A. (2018). Konstruksi Kurikulum Sains Islam Keindonesiaan (Integrasi Islam, Sains Kealaman, Sains Humaniora Dan Keindonesiaan). EDUKASI: Jurnal Penelitian Pendidikan Agama Dan Keagamaan. https://doi.org/10.32729/edukasi.v16i1.46o

Narut, Y. F., \& Supradi, K. (2019). Literasi sains peserta didik dalam pembelajaran ipa di indonesia. Jurnal Inovasi Pendidikan Dasar.

Nofiana, M., \& Julianto, T. (2018). Upaya Peningkatan Literasi Sains Siswa Melalui Pembelajaran Berbasis Keunggulan Lokal. Biosfer : Jurnal Tadris Biologi. https://doi.org/10.24042/biosf.v9i1.2876

Pratiwi, A. (2018). Pengaruh Kompetensi Pedagogik Guru dan Motivasi Belajar terhadap Prestasi Siswa di SMP IT AT-Taqwa. Inspirasi Manajemen Pendidikan.

Purnamawanti, C., Suliswiyadi, S., \& Nugroho, I. (2018). Pengaruh Kompetensi Pedagogik Guru Kelas Terhadap Hasil Belajar IPA di MI Muhammadiyah Kalibanger Kabupaten Temanggung. Tarbiyatuna. https://doi.org/10.31603/tarbiyatuna.v9i1.2088

Rahayu, S. (2016). Menyiapkan Calon Guru Dalam Berliterasi Sains Melalui Pembelajaran Berkonteks Explisit Nature of Science (NOS). Konvensi Nasional Pendidikan Indonesia (KONASPI) VII.

Rahayu, S. (2017). Mengoptimalkan Aspek Literasi dalam Pembelajaran Kimia Abad 21. Prosiding Seminar Nasional Kimia UNY 2017 Sinergi Penelitian Dan Pembelajaran Untuk Mendukung Pengembangan Literasi Kimia Pada Era Global.

Rahmawati, R. D., \& Bakhtiar, N. (2019). Pembelajaran IPA Berbasis Integrasi Islam-Sains pada Pokok Bahasan Penciptaan Alam Semesta dan Tata Surya. Journal of Natural Science and Integration. https://doi.org/10.24014/jnsi.vii2.6599

Rasyid, M. M. (2016). Islam Rahmatan Lil Alamin Perspektif KH. Hasyim Muzadi. Epistemé: Jurnal Pengembangan Ilmu Keislaman. https://doi.org/10.21274/epis.2016.11.1.93-116

Rizkita, L., Suwono, H., \& Susilo, H. (2016). Analisis Kemampuan Awal Literasi Sains Siswa SMA Kota Malang. Prosiding Seminar Nasional II. 
Rohmatika, R. V. (2019). Pendekatan Interdisipliner dan Multidisipliner Dalam Studi Islam. Al-Adyan: Jurnal Studi Lintas Agama. https://doi.org/10.24042/ajsla.v14i1.4681

Saftri, E., \& Sa'dudin, I. (2019). Aplikasi Integrasi Interkoneksi Keilmuan Di Lembaga Pendidikan Tinggi. Tadrib: Jurnal Pendidikan Agama Islam. https://doi.org/10.19109/tadrib.v5i1.2731

Sakti, T. K., Hairunisya, N., \& Sujai, I. S. (2019). Pengaruh Kompetensi Pedagogik Guru dan Gaya Belajar Siswa Terhadap Prestasi Belajar Siswa Pada Mata Pelajaran IPS. JURNAL PENDIDIKAN ILMU SOSIAL. https://doi.org/10.17509/jpis.v28i1.12818

Salmawati, Rahayu, T., \& Lestari, W. (2017). Kontribusi Kompetensi Pedagogik , Kompetensi Profesional dan Motivasi Kerja terhadap Kinerja Guru Penjasorkes SMP di Kabupaten Pati. Journal of Physical Education and Sports.

SapIslamic educationle, N. (2017). Pengaruh Kompetensi Pedagogik, Kompetensi Profesional , dan Sikap Profesi Guru Tehadap Kinerja Penilaian Guru di Sekolah Dasar. Jurnal Teknologi Pendidikan. https://doi.org/10.108o/08897077.2014.993491

Supriyono, A. (2017). Pengaruh Kompetensi Pedagogik, Profesional, Dan Motivasi Kerja Terhadap Kinerja Guru Sekolah Dasar. Jurnal Pendidikan. https://doi.org/10.33830/jp.v18i2.269.2017

Susanti, E., \& Syam, S. S. (2017). Peran Guru dalam Meningkatkan Kemampuan Literasi Matematika Siswa Indonesia. SEMINAR MATEMATIKA DAN PENDIDIKAN MATEMATIKA.

Susena, K. C., Huda, M., Maseleno, A., Sahoo, B. P., \& Kaur, K. (2021). A study on impact of PSL on gross NPAS of nationalised banks: an empirical approach. Linguistics and Culture Review, $5\left(\mathrm{~S}_{3}\right)$.

Sutarmanto. (2015). Kompetensi Dan Profesionalisme Guru. Jurnal Visi Ilmu Pendiidkan.

Winarti, W. (2017). Pengembangan Perangkat Pembelajaran Fisika Bermuatan Integrasi Islam-Sains Untuk Menanamkan Nilai-Nilai Spiritual Siswa Madrasah Aliyah. Jurnal Pendidikan Fisika Dan Keilmuan (JPFK). https://doi.org/10.25273/jpfk.vii2.12

Winarto, W., Zahro, U. C., \& Ardiyansyah, A. (2018). Pengembangan Perangkat Pembelajaran Berbasis Model Belajar Siswa Aktif dengan Pendekatan Al-Quran, Sains, dan Karakter (ALSAK) bagi Siswa Sekolah Dasar. JIPVA. https://doi.org/10.31331/jipva.v2i1.593

Winata, A., Cacik, S., \& Widiyanti, I. S. R. (2018). Kemampuan Awal Literasi Sains Peserta Didik Kelas V Sdn Sidorejo I Tuban Pada Materi Daur Air. JTIEE.

Wulandari, D. (2012). Pengaruh Kompetensi Pedagogik dan Kompetensi Profesional Guru terhadap Economic Literacy melalui Prestasi Belajar Siswa Kelas XII IPS di SMA Kota Malang. Jurnal Pendidikan Humaniora.

Yuliawati, F., Rokhimawan, M. A., \& Suprihatiningrum, J. (2013). Pengembangan modul pembelajaran sains berbasis integrasi islam-sains untuk peserta didik difabel netra mi/sd kelas 5 semester 2 materi pokok bumi dan alam semesta. Jurnal Pendidikan IPA Indonesia. https://doi.org/10.15294/jpii.v2i2.2719

Yulyanti, Y. (2017). Literasi Sains dalam Pembelajaran IPA. Jurnal Cakrawala Pendas.

Zetty Nurzuliana, R., Siti Rashidah, A. R., Norshilawani, S., Ahmad Syafiq, M. R., \& Zanaton, I. (2017). Pengintegrasian Ilmu Aqli Dan Naqli Melalui Pendekatan "Lesson Study" Di Maahad Tahfiz Sains Negeri Selangor. E-Jurnal Penyelidikan Dan Inovasi.

Zuriyani, E. (2011). Literasi Sains Dan Pendidikan. Jurnal Sains Dan Pendidikan, 13. https://doi.org/10.1007/SpringerReference_300852 